\title{
Semi-Continuous Froth Discharge to Reduce Entrainment of Fine Particles in Flotation Cells Subject to Low-Mineralized Froths
}

\author{
Juan Yianatos *, Paulina Vallejos ${ }^{\circledR}$, Luis Vinnett $@$ and Sebastián Arriagada \\ Department of Chemical and Environmental Engineering, CASIM, Federico Santa María Technical University, \\ Valparaiso 2390123, Chile; paulina.vallejos@usm.cl (P.V.); luis.vinnett@usm.cl (L.V.); \\ sebastian.arriagadag@usm.cl (S.A.) \\ * Correspondence: juan.yianatos@usm.cl
}

Received: 21 July 2020; Accepted: 3 August 2020; Published: 5 August 2020

check for updates

\begin{abstract}
An operational strategy is proposed to improve the metallurgical performance of flotation cells subject to low-mineralized froths. This strategy consists of using a semi-continuous discharge into the concentrate, in which the froth is operated under loading and unloading periods. A transient model is developed to evaluate the proposed approach. The model is calibrated using experimental data from two industrial flotation banks. The metallurgical performances of the last cells of these banks are then simulated, considering the semi-continuous froth discharge. The results show that the semi-continuous mode significantly reduces gangue entrainment, improving the concentrate grade while maintaining approximately the same recovery. The semi-continuous strategy demonstrates good potential to enhance the metallurgical indexes under low-mineralized froths, as those in the last cells of rougher flotation banks.
\end{abstract}

Keywords: flotation; froth; entrainment; flotation modeling; semi-continuous froth discharge

\section{Introduction}

Selective true flotation and non-selective entrainment are the main recovery mechanisms in froth flotation [1]. The metallurgical performance in any industrial flotation machine is the result of their relative contribution to the concentrate flowrates [2]. In rougher flotation circuits, the first cells usually present higher recoveries and concentrate grades, which steadily decrease down the bank. The mineral exhaustion leads to these trends as the feed progresses throughout the circuit, decreasing the froth mineralization in the last cells of the banks.

The low mineralization in the last cells typically produces a detrimental effect on the metallurgical performance, which is observed by low incremental recoveries and a larger decrease in concentrate grades. The froths in these cells are typically less stable due to the scarcity of hydrophobic particles attached to the bubbles [3,4]. Therefore, entrainment becomes proportionally more significant, resulting in a decrease in the incremental concentrate grades. The control of the froth depth in these cells is challenging due to the low froth stability. The industrial experience has shown the difficulties to form froths in the last cells of a bank and keep a continuous discharge of solids into the concentrate [2].

In solvent extraction (SX) and electrowinning (EW) plants, contamination of the electrolyte increases operating costs and reduces the quality of the metal product. Any solvent remaining in the raffinate stream represents a loss of solvent and hence an increase in operating costs [5]. To remove or recover the organic solvent in both the electrolyte and raffinate streams, Jameson cells operating with a semi-continuous discharge have been used to separate the organic drops from the electrolyte. In this operation, air bubbles collect the organic drops, which are transported to the top of the collection 
zone where an organic layer is formed and periodically discharged. This work proposes a similar operating strategy to reduce the entrained material in flotation cells with low froth mineralization (e.g., the last cell of rougher flotation banks). This strategy consists of a semi-continuous discharge mode, in which the froth is operated under loading and unloading periods. A simplified model was developed and calibrated from industrial data to evaluate the proposed approach, using first-order relationships (recovery rates) for the pulp and froth phases.

\section{Process Simulation}

A transient model was developed to evaluate the metallurgical performance of flotation cells operated under a semi-continuous froth discharge. The model was calibrated using data from two industrial flotation banks. The metallurgical results ( $\mathrm{Cu}$ recovery and $\mathrm{Cu}$ concentrate grade) of the last cell of each bank were then simulated under a semi-continuous discharge mode. The results were compared with those obtained under a normal discharge operation (continuous discharge).

The following assumptions were made:

- The pulp and froth zones were modelled as a continuous stirred tank reactor (CSTR) and a plug flow reactor (PFR), respectively;

- Two minerals were considered: A floatable valuable mineral (chalcopyrite, with mean liberation coefficient of 70\%) and non-floatable gangue;

- Constant superficial gas rate $\left(J_{\mathrm{G}}\right)$ of $1 \mathrm{~cm} / \mathrm{s}$ and Sauter mean diameter $\left(D_{32}\right)$ of $1.2 \mathrm{~mm}$ were assumed;

- The collection rate of the valuable mineral (true flotation) was assumed to be a deterministic first-order rate constant;

- Due to the water transport into the concentrate, gangue and a fraction of the valuable mineral are recovered by entrainment;

- The particles and water enter the froth zone at different rates;

- In the froth phase, the valuable mineral, gangue and water are transported from the interface to the top of the froth. In this process, some particles (attached or entrained) and a fraction of the water drop back to the pulp phase. Two first-order rate constants were then considered for each component (minerals and water), one for the upward-flowing stream and the other for the drop-back stream.

The equations that describe the flotation system are:

$$
\begin{gathered}
\frac{\partial C_{\text {Cu,pulp }}}{\partial t}=\frac{F_{\text {feed }}}{V_{\text {cell }}} * X_{C u, \text { feed }}-\frac{F_{\text {tailings }}}{V_{\text {cell }}} * X_{\text {Cu,pulp }}-k_{C u, p u l p} * C_{C u, p u l p}+\frac{F_{C u, \text { downwards }}(z=0)}{V_{\text {cell }}} \\
\frac{\partial C_{i, \text { froth }}}{\partial t}=\frac{\partial}{\partial z}\left(\frac{F_{i, \text { upwards }}}{A(z)}\right)-\frac{\partial}{\partial z}\left(\frac{F_{i, \text { downwards }}}{A(z)}\right)
\end{gathered}
$$

Equation (1) corresponds to the mass balance in the pulp phase (CSTR), whereas Equation (2) represents the mass balance in the froth phase (PFR). C, F, $V_{\text {cell }}, X, k_{C u, p u l p}, A(z), t$ and $z$ are the concentration, mass flowrate, cell volume, grade, collection rate constant, froth cross-sectional area, time and space coordinate, respectively. The subscript " $i$ " refers to valuable material, gangue or water. $F i$, upwards and $F i$, downwards are the upwards and downwards mass flowrates of the component $i$ into the froth phase. These variables were estimated using the approach proposed by Moys [6]:

$$
\frac{\partial F_{i, j}}{\partial z}=-\frac{k_{i, j} * A(z) * F_{i, j}}{G}
$$

In Equation (3), $k_{i, j}$ is a first-order rate constant in the froth phase for the component $i$ and $G$ represents the volumetric air flowrate. The subscript " $j$ " refers to upwards or downwards flowrates.

The upwards flowrates of the entrained material and water at $z=0$ were assumed to be constant and were calculated by the methodology reported by Moys [6]. 
The model parameters were estimated using experimental data obtained from metallurgical surveys conducted in two industrial flotation circuits (A and B). Vallejos and Yianatos [7] described these circuits and the sampling methodology. Circuit A consists of nine $130 \mathrm{~m}^{3}$ cells and represents the typical operation in the last cells of rougher banks, with low incremental recovery and low mass pull. Circuit B consists of six $250 \mathrm{~m}^{3}$ cells and illustrates a condition with a moderate low incremental recovery and a relatively high mass pull at the end of the circuit. Steady state was assumed in the parameter estimation. Thus, the mass balances of valuable mineral, gangue and water in the last cells allowed for the modeling of the recoveries and grades as well as the total solid and water flowrates into the concentrate. The rate parameters were then estimated by minimizing the sum of squared residuals of these mass balances. The upward water flowrate across the pulp-froth interface was derived from the gas dispersion parameters, using the approach proposed by Moys [6]. Similarly, the upward entrained solid at the interface level is related to the water flowrate crossing the pulp-froth interface. The input parameters in the flotation model were operating variables such as feed flowrate, feed grade, solid percentage (by mass), mean residence time and froth depth.

The semi-continuous operation in the last cell of circuits A and B was defined according to:

- Loading period (50 $\mathrm{min}$ ). The froth depth increases $10 \mathrm{~cm}$ to accumulate valuable material in the froth with no concentrate discharge. This action is carried out after every unloading period;

- Unloading period (10 $\mathrm{min})$. The froth depth decreases $10 \mathrm{~cm}$ to force the concentrate discharge. This action is carried out after every loading period.

\section{Results and Discussion}

\subsection{Mass Balance}

Table 1 shows the operating conditions in the last cells of circuits A and B, the experimental and modelled metallurgical results (recovery, concentrate grade and mass recovery) and the fitted parameters. The results show a good agreement between the experimental data and the modelled metallurgical indexes for both circuits.

Table 1. Operating conditions, fitted parameters and metallurgical results in the last cell of circuits A and $\mathrm{B}$.

\begin{tabular}{|c|c|c|c|c|c|c|c|}
\hline $\begin{array}{l}\text { Operating Conditions } \\
\text { (Last Cell) }\end{array}$ & Unit & Cell A & Cell B & $\begin{array}{c}\text { Fitted Parameters } \\
\text { (First-Order Rate Constants) }\end{array}$ & Unit & Cell A & Cell B \\
\hline Feed flowrate & tph & 681 & 679 & \multirow{2}{*}{$\begin{array}{c}\text { Collection rate constant } \\
\text { Upward rate constant of valuable } \\
\text { mineral }\end{array}$} & $\min ^{-1}$ & 0.03 & 0.28 \\
\hline Feed Grade & $\%$ & 0.052 & 0.069 & & $\min ^{-1}$ & 3.60 & 3.37 \\
\hline Solid content & $\%$ & 34 & 25 & $\begin{array}{c}\text { Downward rate constant of } \\
\text { valuable mineral }\end{array}$ & $\min ^{-1}$ & 2.17 & 1.48 \\
\hline Froth Depth & $\mathrm{cm}$ & 10 & 8 & $\begin{array}{l}\text { Upward rate constant of entrained } \\
\text { material }\end{array}$ & $\min ^{-1}$ & 2.70 & 3.02 \\
\hline Cell volume & $\mathrm{m}^{3}$ & 130 & 250 & $\begin{array}{c}\text { Downward rate constant of } \\
\text { entrained material }\end{array}$ & $\min ^{-1}$ & 3.01 & 2.50 \\
\hline \multirow[t]{2}{*}{ Mean residence time } & \multirow[t]{2}{*}{$\min$} & \multirow[t]{2}{*}{4.2} & \multirow[t]{2}{*}{5.6} & Upward rate constant of water & $\min ^{-1}$ & 4.16 & 3.83 \\
\hline & & & & Downward rate constant of water & $\min ^{-1}$ & 3.33 & 3.03 \\
\hline $\begin{array}{l}\text { Experimental } \\
\text { metallurgical result }\end{array}$ & & & & Modelled Metallurgical Result & & & \\
\hline Cu Recovery & $\%$ & 4.3 & 47.3 & Cu Recovery & $\%$ & 4.3 & 46.8 \\
\hline Cu Concentrate Grade & $\%$ & 0.75 & 1.13 & Cu Concentrate Grade & $\%$ & 0.73 & 1.12 \\
\hline Mass Recovery & $\%$ & 0.30 & 2.88 & Mass Recovery & $\%$ & 0.32 & 2.88 \\
\hline
\end{tabular}

Figure 1 shows the cumulative $\mathrm{Cu}$ recoveries and concentrate grades obtained from the metallurgical surveys in circuits A and B. The results follow typical trends in rougher flotation circuits operated with low feed grades. The cumulative recovery presented an increasing trend approaching a plateau in circuit $\mathrm{A}$, and a sustained increasing trend in circuit B (shorter circuit, with the sixth cell out of operation). The cumulative concentrate grades decreased down the flotation banks. 


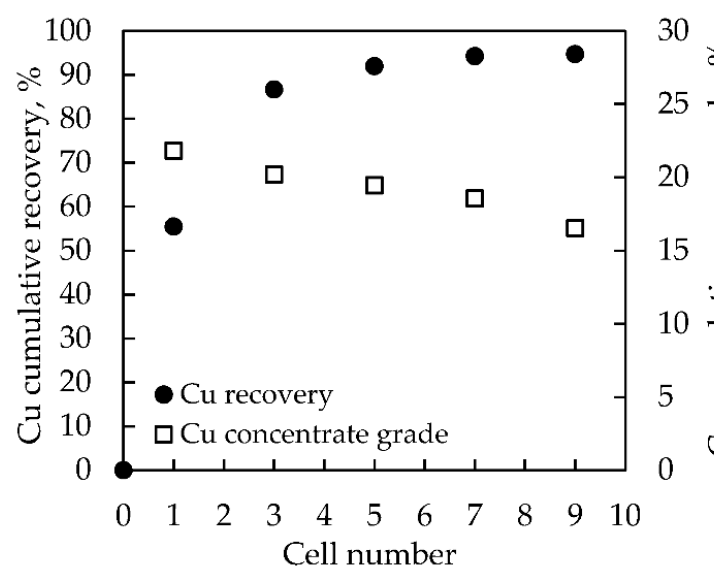

(a)

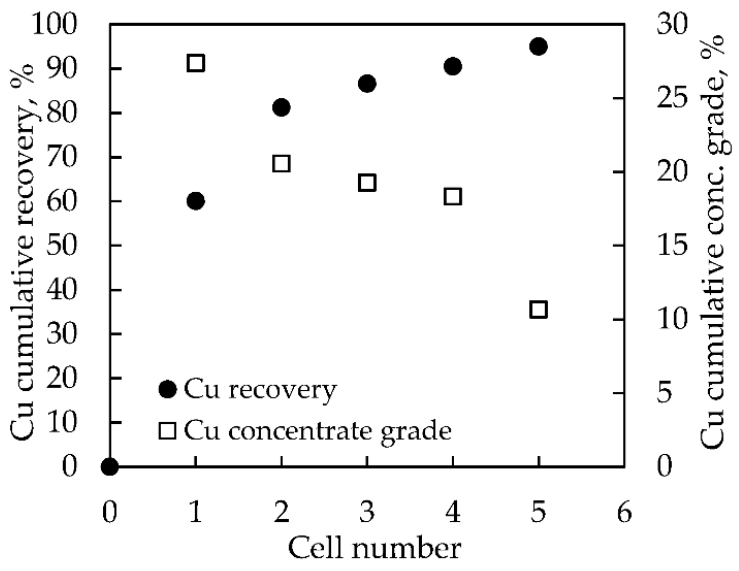

(b)

Figure 1. Cumulative recoveries and concentrate grades, circuits A (a) and B (b).

The first cells of the bank typically recover a significant fraction of the valuable minerals, leaving less floatable material down the bank for collection and transport into the froth. Therefore, the incremental $\mathrm{Cu}$ recovery, relative to the incremental mass recovery, is typically lower in the last cells of the bank and entrainment becomes proportionally more significant. This condition produces gradual or abrupt decreases in the concentrate grades depending on the flotation mass pull.

\subsection{Semi-Continuous Cell Simulation}

The last operating cells of each circuit (A and B) were simulated, considering the semi-continuous discharge mode. The froth depths for the loading and unloading intervals in cell A were 20 and $10 \mathrm{~cm}$, respectively. For Cell B, these froth depths were 18 and $8 \mathrm{~cm}$, respectively. These froth depths were chosen to emulate the actual industrial operation.

Figure 2 shows the concentrate grades of chalcopyrite and gangue in the froth of Cell A as a function of time, under normal and semi-continuous discharge. Similar behaviour was observed in Cell B. Figure 2a shows that the chalcopyrite concentrate grade varied from $11.2 \%$ to $4.3 \%$ in the discharge period of the semi-continuous mode, which is higher than the $2.1 \%$ for the continuous mode (dashed lines). Figure $2 \mathrm{~b}$ shows that the gangue concentrate grade varied from $88.8 \%$ to $95.7 \%$ in the same period, which is lower than the $97.9 \%$ for the continuous mode. The larger relative content of chalcopyrite during de discharge period allows for a significant decrease in the total gangue recovery.

Table 2 compares the semi-continuous operation with the baseline (continuous froth discharge). The semi-continuous approach: (i) Slightly increased the $\mathrm{Cu}$ recovery, (ii) increased the concentrate grade by 3.5 and 2.3 times in circuits A and B, respectively, and (iii) significantly reduced the mass recovery in the last cells. These results indicate that the main effect of the proposed strategy is an entrainment reduction, allowing for an improvement in selectivity without a detrimental impact on the $\mathrm{Cu}$ recovery.

Table 2. Comparison of simulation results for continuous and semi-continuous operations. Last flotation cell.

\begin{tabular}{|c|c|c|c|c|c|c|c|}
\hline Cell A & Unit & $\begin{array}{l}\text { Baseline } \\
\text { Continuous } \\
\text { Operation }\end{array}$ & $\begin{array}{l}\text { Semi-Continuous } \\
\text { Operation } \\
\text { (Cycle: } 1 \text { h) }\end{array}$ & Cell B & Unit & $\begin{array}{l}\text { Baseline } \\
\text { Continuous } \\
\text { Operation }\end{array}$ & $\begin{array}{c}\text { Semi-Continuous } \\
\text { Operation } \\
\text { (Cycle: } 1 \text { h) }\end{array}$ \\
\hline \multirow{3}{*}{$\begin{array}{l}\text { Cu Recovery } \\
\text { Cu concentrate } \\
\text { grade } \\
\text { Mass Recovery }\end{array}$} & $\%$ & 4.3 & 5.1 & \multirow{3}{*}{$\begin{array}{c}\text { Cu Recovery } \\
\text { Cu concentrate } \\
\text { grade } \\
\text { Mass Recovery }\end{array}$} & $\%$ & 46.8 & 49.9 \\
\hline & $\%$ & 0.73 & 2.52 & & $\%$ & 1.12 & 2.63 \\
\hline & $\%$ & 0.32 & 0.10 & & $\%$ & 2.88 & 1.30 \\
\hline
\end{tabular}




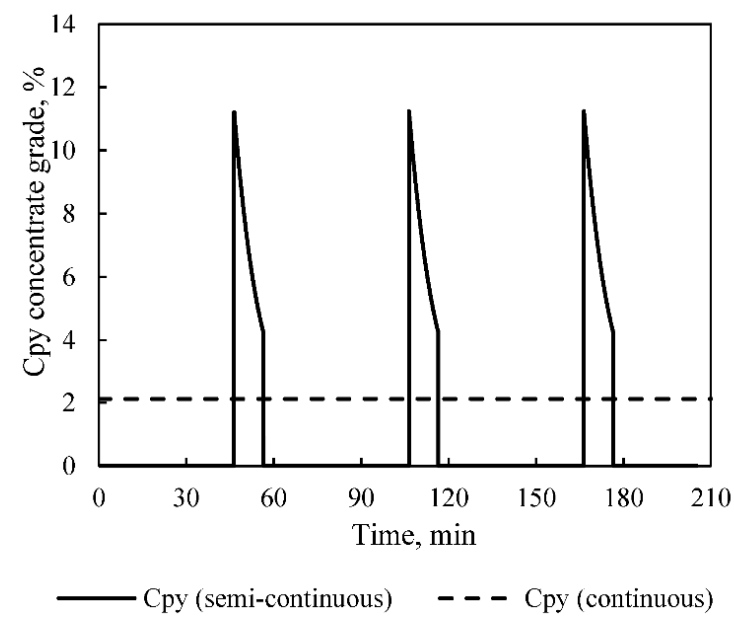

(a)

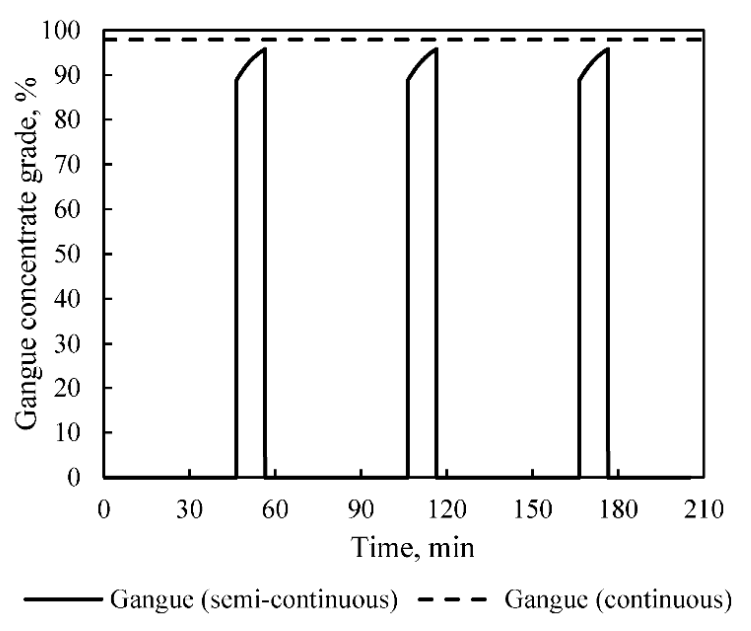

(b)

Figure 2. Semi-continuous operation (simulated) versus continuous operation (experimental). Concentrate grades in the last cell of circuits A, (a) chalcopyrite, and (b) gangue.

In semi-continuous operation, gangue has less chance to accumulate in the froth. Gangue enters the froth by entrainment and drops back to the collection zone due to the water drainage. The valuable minerals (floatable), which are scarcely present in the feed, are collected and gradually accumulated in the froth, increasing the froth stability. In the unloading period, the discharged valuable mineral is then significantly higher regarding the continuous operation and can be comparable to that recovered in the entire cycle under normal mode. As the unloading period represents about $16.6 \%$ of the cycle, the gangue recovery decreases, which increases the chalcopyrite concentrate grade at the similar recovery of this valuable mineral, as shown in Figure 2.

Table 3 shows the mass flowrates recovered by entrainment in the last cells of both circuits. The effect of the semi-continuous approach on reducing entrainment was more significant in circuit $B$ $(38.6 \%)$, in which the last cell was subject to higher mass recovery. However, the entrainment reduction of $8.3 \%$ in circuit A was not negligible. Therefore, the semi-continuous operation proved to be an alternative for decreasing entrainment in flotation cells with low-mineralized froths.

Table 3. Entrainment in circuits A and B.

\begin{tabular}{cccc}
\hline Entrainment & Circuit & A & B \\
\hline Overall circuit & ton $/ \mathrm{h}$ & 15.7 & 27.7 \\
Last cell (continuous) & ton $/ \mathrm{h}$ & 2.0 & 18.7 \\
Last cell (semi-continuous, cycle: $1 \mathrm{~h}$ ) & ton $/ \mathrm{h}$ & 0.6 & 8.0 \\
Reduction in overall circuit entrainment & $\%$ & 8.3 & 38.6 \\
(semi-continuous mode in the last cell) & & & \\
\hline
\end{tabular}

Figure 3 shows the grade-recovery profiles in circuits A and B from the experimental data. The potential change in the grade-recovery curve when replacing the metallurgical with the simulated results in the last cells is also presented. Only the last three cells are shown to focus on the differences between the semi-continuous and continuous froth discharge at the end of the circuit. The semi-continuous mode allowed for a better metallurgical performance, especially in terms of selectivity, improving the incremental and cumulative concentrate grades. Therefore, the proposed approach shows the potential for reducing entrainment in the last cells of rougher flotation banks. Higher froth depths with no discharge in the loading period improve the froth stability by increasing the valuable content in the froth, as commonly observed in plant practice. 


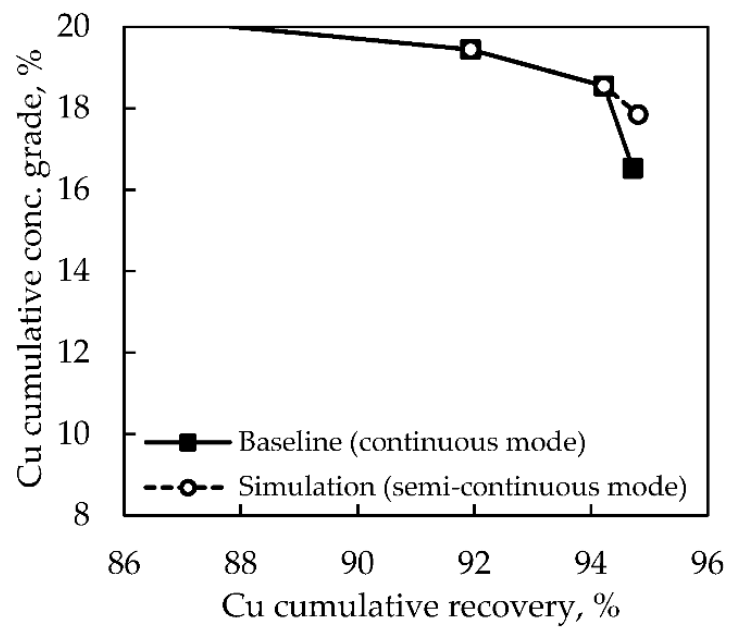

(a)

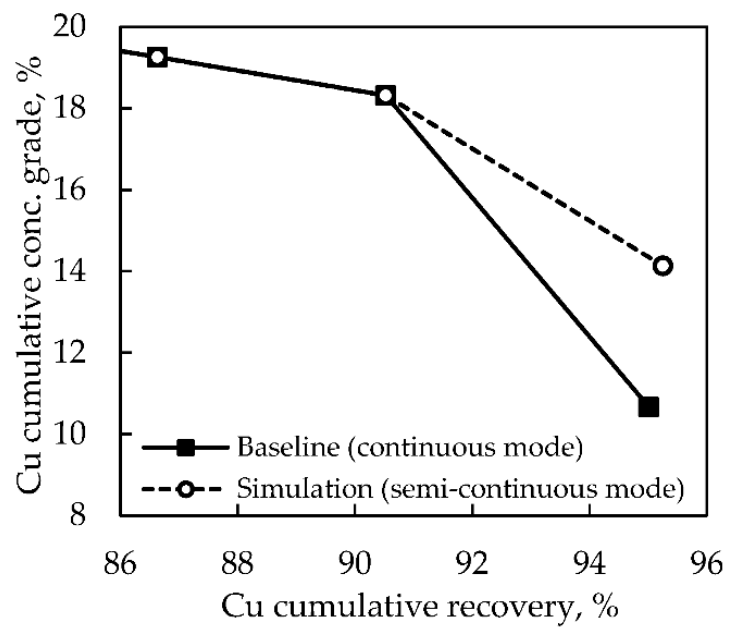

(b)

Figure 3. Comparison of continuous (experimental) and semi-continuous (simulated) grade-recovery profiles: (a) circuit A, and (b) circuit B.

Results of Figures 2 and 3 and Tables 2 and 3 showed the advantages of the semi-continuous strategy in flotation cells subject to low-mineralized froths. These results were determined from the model assumptions and simplifications detailed in Section 2. On this subject, further developments must be made to assess the model structure under a wider range of operational conditions and cell designs. For example, different feed and pulp properties that affect the froth transport must be studied to consolidate the parameters of Table 1 (e.g., feed size distribution, pulp density, viscosity and others). The sensitivity of the proposed strategy to the gas rates and residence times must be also taken into consideration. Additional sampling surveys are then necessary to generalize the results reported here. Practical constraints, such as valve limitations, transport delays, rise and settling times of the control loops must be experimentally studied and included in the simulations. Thus, optimizing strategies may potentially be studied from simulations, prior to industrial trials and implementations.

The industrial application of this methodology requires not only automatic control of the froth depth but also adequate regulatory valves and calibrated level sensors. Froth vision systems will be useful for measuring the froth discharge velocity to set the froth loading and unloading periods. This instrumentation is commonly available in large flotation cells. The definition of the optimal loading and unloading periods and froth depth ranges may be a relevant challenge at industrial scale. The feasibility to set and keep the semi-continuous operation will be a function of several ore, pulp and froth properties such as content of solids in suspension, froth viscosity, particle size distribution and others. Complementary regulation of the gas flowrate may be required to prevent froth overflowing during the loading period.

\section{Conclusions}

A semi-continuous operational strategy was presented to reduce gangue entrainment in flotation cells subject to low froth mineralization. This strategy consisted of two operation modes in the froth: Loading and unloading stages.

A transient model was developed and calibrated with data from two industrial surveys. This model was used to simulate the semi-continuous strategy. The simulation results showed that the semi-continuous approach significantly reduces the relative amount of accumulated gangue in the froth for similar $\mathrm{Cu}$ recoveries in the last cell of a flotation bank. The lower gangue content in the froth finally reduced gangue entrainment by $8.3 \%$ to $38.6 \%$ in the two simulated cells, which were dependent on the mass recovery in the baselines (continuous froth discharge). 
The semi-continuous operation demonstrated good potential as an alternative for reducing entrainment in flotation, particularly for low-mineralized froths as those typically observed in the last cells of rougher banks. Further developments must be made to consolidate the model parameters and to industrially implement the proposed strategy.

Author Contributions: Conceptualization, J.Y. and P.V.; methodology, J.Y. and L.V.; software, S.A.; validation, P.V. and L.V.; formal analysis, S.A.; investigation, J.Y. and P.V.; resources, J.Y.; writing-original draft preparation, J.Y., P.V. and S.A.; writing-review and editing, L.V.; visualization, P.V.; supervision, J.Y.; project administration, J.Y. and P.V. All authors have read and agreed to the published version of the manuscript.

Funding: This research and the APC were funded by Agencia Nacional de Investigación y Desarrollo (ANID), Fondecyt Project 1201335.

Acknowledgments: The authors are grateful to Federico Santa María Technical University for providing administrative and technical support for process modeling and control research.

Conflicts of Interest: The authors declare no conflict of interest.

\section{References}

1. Wang, L.; Peng, Y.; Runge, K.; Bradshaw, D. A review of entrainment: Mechanisms, contributing factors and modelling in flotation. Miner. Eng. 2015, 70, 77-91. [CrossRef]

2. Wills, B.; Finch, J. Wills' Mineral Processing Technology., 8th ed.; Elsevier: Amsterdam, The Netherlands, 2017.

3. Schwarz, S. and Grano, S. Effect of particle hydrophobicity on particle and water transport across a flotation froth. Colloids Surf. A: Physicochem. Eng. Asp. 2005, 256, 157-164. [CrossRef]

4. Zanin, M.; Wightman, E.; Grano, S.; Franzidis, J. Quantifying contributions to froth stability in porphyry copper plants. Int. J. Miner. Process. 2009, 91, 19-27. [CrossRef]

5. Glencore Technology Jameson Cell. Available online: https:/www.jamesoncell.com/en/applications/Pages/ solvent-extraction.aspx (accessed on 1 May 2020).

6. Moys, M. A study of a plug-flow model for flotation froth behaviour. Int. J. Miner. Process. 1978, 5, 21-38. [CrossRef]

7. Vallejos, P.; Yianatos, J. Analysis of industrial flotation Circuits Using Top-of-froth and Concentrate Mineralogy. Miner. Process. Extr. Metall. Rev. 2019. [CrossRef] 